\title{
Conservative Treatment of Epistaxis: Comparing Oxytetracycline with Sodium Pentaborate Pentahydrate
}

\section{Tekrarlayan Anterior Epistaksis Tedavisinde Topikal Sodyum Pentaborat Pentahidrat Uygulaması ile Topikal Oksitetrasiklin Uygulamasının Karşılaştırılması}

\section{(D) Ayşe Sezim Şafak¹, (D) Fikrettin Şahin²}

1 İstanbul Yeniyüzyll University Faculty of Medicine, Department of Audiometry, İstanbul, Turkey

2 Yeditepe University Faculty of Medicine, Department of Genetics and Bioengineering, İstanbul, Turkey

\section{Abstract}

Objective: In daily practice, the treatment of epistaxis is generally conservative. Surgical options, which are rarely used, also exist. However, a gold standard treatment option - especially one that is easily applied without need for specialist intervention- has not been introduced. Topical agents are easy to apply and are widely used but success is moderate to low, which demonstrates the requirement for new agents. Sodium pentaborate pentahydrate (SPP) is a natural mineral which has drawn attention in the medical field due to its remarkable wound healing properties. Our aim was to compare the results of topical SPP and oxytetracycline in the treatment of anterior epistaxis.

Method: A total of 66 patients with recurrent anterior epistaxis were included in the study which was performed at the Clinic of Otorhinolaryngology Gebze Central Hospital from January 2018 to February 2018. The age, gender, date of application, medications, chronic illnesses, the frequency of epistaxis after treatment (first week) were recorded. Additionally, we recorded the pre- and post-treatment SNOT22 scores and Kisselbach area measurement results of all patients. Thirty-two patients received topical SPP gel and 34 received topical oxytetracycline treatment. Groups were similar in terms of age and gender.

Results: SPP gel and oxytetracycline treatments mostly showed similar results. However, the frequency of epistaxis during the first week after treatment was significantly lower with SPP gel treatment.

Conclusion: Our results suggest that SPP gel may be used in the treatment of epistaxis with success similar to that of oxytetracycline. Furthermore, the frequency of epistaxis during the first week after treatment was significantly lower in patients treated with SPP, which is an important advantage.

Keywords: Epistaxis, oxytetracycline, SPP, SNOT 22, topical treatment

\section{Öz}

Amaç: Kulak burun boğaz pratiğinde epistaksis (burun kanaması) tedavisi genellikle konservatiftir. Cerrahi tedavi seçeneği, nadir durumlarda gerekir. Öte yandan uzman muayenesi gerekmeden altın standart kolay uygulanan bir tedavi seçeneği henüz tanımlanmamıştır. Yaygın kullanılan topikal ajanların kullanımları kolaydır, ancak orta ile düşük düzeyde başarı gösterdikleri için yeni tedavi seçenekleri ve medikal tedavi ajanlarına intiyaç vardır. Sodyum pentaborat pentahidrat (SPP) doğal bir mineral olup medikal alanda yara iyileşmesi üzerine belirgin başarısı gözlenmiştir. Biz de çalışmamızda anterior epistaksis tedavisinde hali hazırda yaygın kullanılan topikal oksitetrasiklin ile topikal SPP uygulamasını epistaksis tedavi başarısı olarak karşılaştırmayı hedefledik.

Yöntem: Ocak 2018 ile Şubat 2018 tarihleri arasında Özel Gebze Merkez Hastanesi KBB Kliniği'ne tekrarlayan anterior epistaksis şikayeti ile başvuran toplam 66 hastayı çalışmaya dahil ettik. Hastaların yaş, cinsiyet, başvurma zamanları, kullandıkları ilaçlar, kronik hastalıkları, bir haftalık topikal tedavi sonrasındaki epistaksis sıklığı kaydedildi. Ek olarak tedavi öncesi ve sonrası SNOT-22 skorları ve Kisselbach alanının ölçümleri yapıldı. Otuz iki hastaya topikal SPP jel, 34 hastaya topikal oksitetrasiklin tedavisi uygulandı. Grupların yaş ve cinsiyet aralıkları benzerdi.

Bulgular: Topikal SPP jel ve oksitetrasiklin tedavileri benzer sonuçlar göstermişlerdir. Öte yandan tedavi sonrasındaki ilk haftada görülen epistaksis sıklığı anlamlı olarak SPP jel uygulamasında daha düşük bulunmuştur.

Sonuç: Sonuçlarımız göstermiştir ki, SPP jel epistaksis tedavisinde kullanılabilir, başarısı oksitetrasiklin ile benzerdir. Ayrıca tedavi sonrasındaki ilk haftada epistaksis sıklığının anlamlı derecede az olması da önemli bir avantajdır.

Anahtar kelimeler: Epistaksis, oksitetrasiklin, SPP, SNOT 22, topikal tedavi

Address for Correspondence: Ayşe Sezim Şafak, İstanbul Yeniyüzyıl University Faculty of Medicine, Department of Audiometry, İstanbul, Turkey E-mail: ayse.sezim@yeniyuzyil.edu.tr ORCID: orcid.org/0000-0001-8514-7172 Received: 26.11.2019 Accepted: 26.05.2020

Cite this article as: Sezim Şafak A, Şahin F. Conservative Treatment of Epistaxis: Comparing Oxytetracycline with Sodium Pentaborate. Bagcilar Med Bull 2020;5(2):52-56

${ }^{\circ}$ Copyright 2020 by the Health Sciences University Turkey, Bagcilar Training and Research Hospital Bagcilar Medical Bulletin published by Galenos Publishing House. 


\section{Introduction}

Although only $10 \%$ of patients who suffer from epistaxis apply to hospitals (1), its life-time prevalence of $60 \%$ makes epistaxis a substantial health problem (2). While gender distribution of epistaxis is similar, the frequency increases with age. Epistaxis is categorized according to the location of bleeding (anterior, posterior). Anterior epistaxis is much more frequent compared to posterior epistaxis which may be more severe and may require surgical intervention (3). Even though most epistaxis episodes regress without any complications, controlling the bleeding can be difficult with available treatment options in some cases. However, medical treatment for epistaxis is usually both therapeutically and prophylactically effective (4). On a side note, etiological factors such as hypertension and hematological disorders must be identified and corrected during the initial approach. Surgical options for the treatment of epistaxis also exist; however, surgical intervention is rarely performed due to rare but serious complications, including cerebrovascular events, septal perforation, blindness, ulcerations, altered mental status, ophthalmoplegia and tissue necrosis (5-7). Conservative management includes combinations of external pressure, nasal packing, anterior cautery, humidification and topical agents (8).

Sodium pentaborate pentahydrate (SPP), which has been shown to positively affect wound healing and fibroblast activation, is a recent addition to medical literature and promising results have been achieved in the treatment of many diseases $(9,10)$. Although its role in wound healing has been demonstrated, to our knowledge, it is still unused in the treatment of epistaxis in otorhinolaryngology practice. When previous data are considered, SPP seems to be an ideal candidate for epistaxis treatment due to its woundhealing and antimicrobial properties.

The aim of our study was to compare the treatment results of topical SPP and oxytetracycline in patients with anterior epistaxis.

\section{Materials and Methods}

The current study was conducted on patients who applied to the Clinic of Otorhinolaryngology Gebze Central Hospital with epistaxis from January 2018 to February 2018. The inclusion criteria were as follows: experiencing at least 3 cases of spontaneous anterior (Kisselbach region) epistaxis and not having a history of recent upper respiratory tract infection. Exclusion criteria were determined as follows: having a diagnosis of hypertension, chronic sinusitis or allergic rhinitis, having an active nasal infection, having recently suffered from nasal trauma, being diagnosed with any type of bleeding disorder, and the use of medications which affect coagulation. We included a total of 66 patients according to these criteria. Ethical approval was obtained from the İstanbul Yeniyüzyll University Medical Faculty Ethical Committee (decision number: 01.02.2018/003). All steps of the study were designed in accordance with the Helsinki Declaration. Informed consent was obtained from all patients.

Patients were divided into two groups according to treatment type. All patients received daily nasal decongestant treatment, regardless of group. In addition to decongestants, patients in the first group received SPP (Dermobor ${ }^{\circledR}$, Bi7Tech, Istanbul, Turkey) treatment (three times a day) while patients in the second group received oxytetracycline (three times a day). The suggested volume of both treatments was $0.1 \mathrm{~mL}$; patients were shown the appropriate amount on a cotton ear swab and were told that the size should be close to the size of a single lentil. Both agents were applied topically and directly on the site of bleeding.

The Sinonazal Outcome test (SNOT-22) test was used to evaluate naso-sinusoidal quality of life. The SNOT-22 is known to be a highly accurate tool for determining the effect of interventions in naso-sinusoidal illnesses. The test is comprised of 6-level Likert-type items (0: no problem, 6: worst possible problem) with a total of 22 questions (11). The final score of the scale may range between 0 and 110 points. The Turkish language reliability and validity study of the test was performed by Hanci et al. (12).

After a patient applied with epistaxis, their history of previous epistaxis and illnesses were assessed in addition to complaints and findings regarding the present event. The age, gender, date of application, medications and chronic illnesses of patients were recorded. The vascularization area $\left(\mathrm{mm}^{2}\right)$ of the Kisselbach region was measured before and after treatment. Size was measured via manual calipers (Elektron Medikal, Ankara, Turkey) with the help of endoscopic visualization of the area. Pre- and posttreatment SNOT-22 tests were completed by all patients. The frequency of epistaxis during the first week after treatment was recorded and all patients attended followup for one month - during which complications were evaluated and treated accordingly. 


\section{Statistical Analysis}

All analyses were performed with SPSS version 21.0. The Shapiro-Wilk test was used to test for normality of distribution. Continuous data were given as mean \pm standard deviation for normally distributed variables and median (minimum - maximum) for non-normally distributed variables. Categorical data were given as frequency (percentage). Age was compared with the independent samples t-test. Bleeding area and SNOT-22 scores before and after treatment were compared with the Wilcoxon Signed Rank tests. For the evaluation of these variables between the groups, we calculated the difference between pre- and post-treatment measurements and compared them with the Mann-Whitney $U$ test (due to non-normal distribution). Bleeding frequency was compared with the Pearson chi-square test. $\mathrm{P}<0.05$ values were accepted to be statistically significant. Power analysis was performed according to a pilot study performed in 5 patients. We found a bleeding area of $10.1 \pm 2.7 \mathrm{~mm}^{2}$ in these patients. Hypothesizing that a reduction of at least $15 \%$ was required to consider the treatment was successful, we found that each group required at least 29 patients with a power of $80 \%$ and an alpha error of $5 \%$.

\section{Results}

A total of 66 patients (33 males and 33 females) with a mean age of $34.4 \pm 10.2$ years were included in the study. Thirtytwo patients (17 males, 15 females) were treated with SPP (group 1) and 34 patients (16 males, 18 females) were treated with oxytetracycline (group 2) (Table 1). There was no significant difference between our groups regarding age and gender. Bleeding area significantly decreased in both groups after treatment ( $\mathrm{p}<0.001$ for each group) (Figure 1). In terms of change in bleeding area, there was no significant difference between the groups $(\mathrm{p}=0.106)$. Compared to the SPP group, bleeding frequency after treatment was significantly higher for the oxytetracycline group $(\mathrm{p}=0.011)$. The SNOT-22 scores of both groups decreased significantly after treatment $(\mathrm{p}<0.001$ for each group). There was no significant difference between the groups regarding the change in SNOT-22 scores ( $\mathrm{p}=0.856$ ) (Figure 2$)$.

\section{Discussion}

In the current study, the efficacy of SPP and oxytetracycline in the treatment of anterior epistaxis were compared by

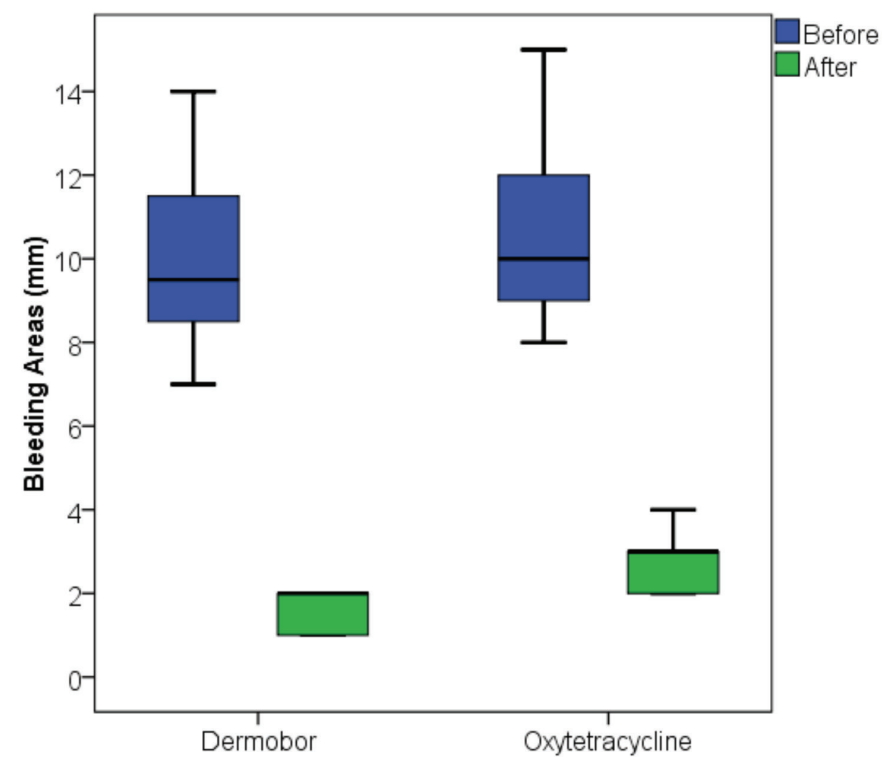

Figure 1. Bleeding area $\left(\mathrm{mm}^{2}\right)$ before and after treatment regarding groups

mm: Millimeter

Table 1. Descriptives and statistical analysis results of our variables

\begin{tabular}{|c|c|c|c|}
\hline & SPP & Oxytetracycline & $\mathbf{p}$ \\
\hline Patient count (n) & 32 & 34 & $\mathrm{~N} / \mathrm{A}$ \\
\hline Age (years) & $33.50 \pm 10.22$ & $35.15 \pm 10.27$ & 0.516 \\
\hline Male & $17(53.1 \%)$ & $16(47.1 \%)$ & 0.805 \\
\hline Bleeding area before treatment $\left(\mathrm{mm}^{2}\right)$ & $9.5(7-14)$ & $10(8-15)$ & \multirow{2}{*}{0.106} \\
\hline Bleeding area after treatment $\left(\mathrm{mm}^{2}\right)$ & $2(1-2)$ & $3(2-4)$ & \\
\hline \multicolumn{4}{|c|}{ Bleeding frequency after treatment (first week) } \\
\hline 0 & $20(62.5 \%)$ & $10(29.4 \%)$ & \multirow{3}{*}{0.011} \\
\hline 1 & $11(34.3 \%)$ & $17(50.0 \%)$ & \\
\hline 2 & $1(3.1 \%)$ & $7(20.6 \%)$ & \\
\hline SNOT-22 score before treatment & $12(7-15)$ & $11.5(8-16)$ & \multirow{2}{*}{0.856} \\
\hline SNOT-22 score after treatment & $2(0-4)$ & $2(0-4)$ & \\
\hline
\end{tabular}

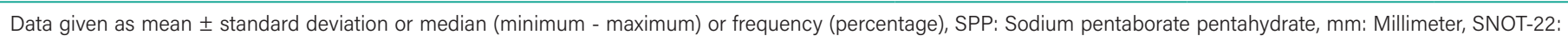
Sinonazal Outcome test 


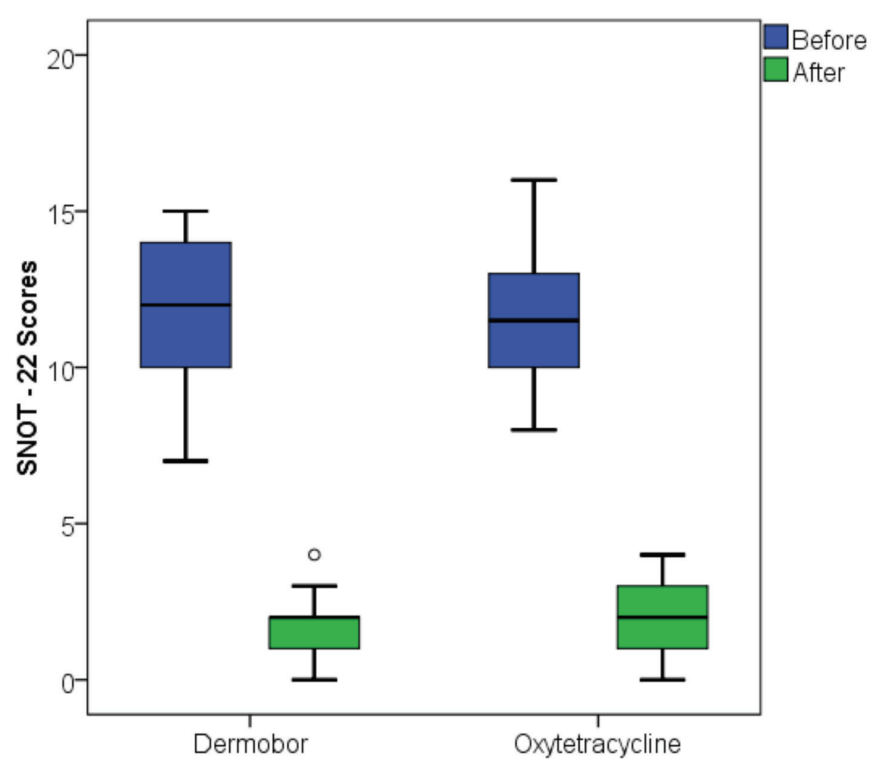

Figure 2. SNOT-22 scores before and after treatment regarding groups

SNOT-22: Sinonasal Outcome test

measuring the changes in bleeding area, the frequency of post-treatment bleeding and SNOT-22 scores. Our results demonstrate that, both SPP and oxytetracycline are effective in treating epistaxis. However, apart from a lower number of recurrent bleeds during the first week after treatment, no major difference was found between these two agents.

Epistaxis is treated with conservative and surgical methods. Conservative treatments include external pressure, nasal packing, anterior cautery, humidification and topical agents (8). Surgical options involve the ligation of maxillary, anterior ethmoid and sphenopalatine artery, and also endoscopic nasal cautery (13). However, in clinical practice, if the bleeding does not sufficiently cease with external pressure and nasal packing, patients are usually informed of surgical options and are directed to otorhinolaryngology clinics (Traboulsi, 2015 \#228). Also, the lack of a widelyaccepted standardized treatment algorithm - or failure to follow available algorithms - may cause insufficient conservative treatment (Tunkel, 2020 \#229). Thus, investigating options for conservative treatment and their success rate is important to increase the number of options in the first-line treatment of epistaxis.

SPP, also named spp., is a rare natural mineral (14) with remarkable wound healing, antimicrobial and fibroblast activation properties $(10,15)$. SPP gel $(0.2 \%$ chlorhexidine digluconate and 3\% SPP) has been used with successful results in various dermatological diseases and wound healing studies $(10,16,17)$. A study on rats by Doğan et al. (18) demonstrated the efficacy of SPP gel in full thickness wounds. The study reported that, while the mechanism of action could not be elucidated, a combination of SPP and pluronics increased the levels of transforming growth factor- $\beta$ and vascular endothelial growth factor which were instrumental in wound healing. They concluded that SPP could be used for the treatment of chronic wounds. Other effects of SPP include increases in metalloproteinase activation, extracellular matrix turnover, ion transport and keratinocyte migration. In the current study, a gel containing SPP was found to be similar to oxytetracycline in the treatment of epistaxis; however, post-treatment bleeding frequency was significantly reduced with SPP compared to oxytetracycline, which is a major advantage. Although the mechanism of action could not be determined in the current study, we believe the effects were related to the repair of mucosal damage, especially considering the fact that none of the patients had any chronic conditions that could increase epistaxis frequency (hypertension, bleeding disorder etc).

There are some limitations to our study. Firstly, we used the SNOT-22 scale and bleeding area measurements for the evaluation; however, these are not entirely objective parameters for the evaluation of treatment success. Secondly, we did not assess bleeding frequency during the week prior to treatment, and this is also a limitation; however, most patients could not recall the number of nose bleeds accurately. Therefore, in order to avoid bias, this datum was not included in the study. Other limitations are: the absence of a control group without treatment (due to ethical concerns) and the lack of a gold standard treatment for epistaxis (which would be used to evaluate the efficacy of the agent). However, these limitations were unavoidable and our aim was to compare SPP with the most frequently used and widely-accepted topical treatment option. The strengths of our study include the fact that we report the efficacy of an agent which is very new to medical literature. Additionally, to our knowledge, this is the first clinical study investigating the use of SPP for the treatment of epistaxis.

\section{Conclusion}

We have demonstrated that SPP may be used in the clinical treatment of anterior epistaxis. Although we were unable to identify the mechanism of action due to the design of the study, it is feasible to suggest that treatment success was associated with the repair of mucosal damage. We believe that further studies with larger patient groups and 
comparisons with different agents may better demonstrate the efficacy of SPP in the treatment of epistaxis.

\section{Ethics}

Ethics Committee Approval: Ethical approval was obtained from the İstanbul Yeniyüzyıl University Medical Faculty Ethical Committee (decision number: 01.02.2018/003).

Informed Consent: All patients' informed consent was taken.

Peer-review: Externally peer-reviewed.

\section{Authorship Contributions}

Concept: A.S.Ş., Design: A.S.Ş., Data Collection or Processing: A.S.Ş., Analysis or Interpretation: A.S.Ş., F.Ş., Writing: A.S.Ş., F.Ş.

Conflict of Interest: No conflict of interest was declared by the authors.

Financial Disclosure: The authors declared that this study has received no financial support.

\section{References}

1. Villwock JA, K Jones. Recent trends in epistaxis management in the United States: 2008-2010. JAMA Otolaryngol Head Neck Surg 2013;139(12):1279-1284.

2. Kucik CJ, Clenney T. Management of epistaxis. Am Fam Physician 2005;71(2):305-311.

3. Viducich RA, Blanda MP, Gerson LW. Posterior epistaxis: clinical features and acute complications. Ann Emerg Med 1995;25(5):592596.

4. Fatakia A, Winters R, Amedee RG. Epistaxis: A Common Problem. The Ochsner Journal 2010;10(3):176-178.

5. Kotecha B, Fowler S, Harkness P, Walmsley J, Brown P, Topham J. Management of epistaxis: a national survey. Ann R Coll Surg Engl 1996;78(5):444-446.

6. Neto PS, Nunes LMA, Gregorio LC, Santos RP, Kosugi EM. Surgical treatment of severe epistaxis: an eleven-year experience. Brazilian Journal of Otorhinolaryngology 2013;79(1):59-64.
7. Dubel GJ, Ahn SH, Soares GM. Transcatheter Embolization in the Management of Epistaxis. Seminars in Interventional Radiology 2013;30(3):249-262.

8. Razdan U, Raizada RM, Chaturvedi VN. Efficacy of conservative treatment modalities used in epistaxis. Indian Journal of Otolaryngology and Head and Neck Surgery 2004;56(1):20-22.

9. Aysan E, Idiz UO, Elmas L, Saglam EK, Akgun Z, Yucel SB. Effects of Boron-Based Gel on Radiation-Induced Dermatitis in Breast Cancer: A Double-Blind, Placebo-Controlled Trial. Journal of Investigative Surgery 2017;30(3):187-192.

10. Doğan A, Demirci S, Cağlayan AB, Kılıç E, Günal MY, Uslu U, et al. Sodium pentaborate pentahydrate and pluronic containing hydrogel increases cutaneous wound healing in vitro and in vivo. Biological trace element research 2014;162(1-3):72-79.

11. Hopkins C, Gillett S, Slack R, Lund VJ, Browne JP. Psychometric validity of the 22-item Sinonasal Outcome Test. Clin Otolaryngol 2009;34(5):447-454.

12. Hanci D, Altun H, Şahin E, Altıntoprak N, Cingi C. Turkish translation, cross-cultural adaptation and validation of the SinoNasal Outcome Test (SNOT)-22. ENT Updates 2015;5(2):5157.

13. Traboulsi H, Alam E, Hadi U. Changing Trends in the Management of Epistaxis. Int J Otolaryngol, 2015;2015:263987.

14. Gong Y, Yatongchai C, Wren AW, Mellott NP. Reintroducing sborgite: Crystallization through exposure of sodium borosilicate glasses to moisture. Materials Letters 2014;136:265-270.

15. Tepedelen BE, Soya E, Korkmaz M. Boric acid reduces the formation of DNA double strand breaks and accelerates wound healing process. Biological trace element research 2016;174(2):309-318.

16. Chen X, Pei Y. Effects of sodium pentaborate pentahydrate exposure on Chlorella vulgaris growth, chlorophyll content, and enzyme activities. Ecotoxicology and environmental safety 2016;132:353-359.

17. Büke Ç. Current Treatment of Diabetic Foot Infections and the Effect of Dermobor. Cyprus Journal of Medical Sciences 2017;2(2):29-34.

18. Doğan A, Demirci S, Cağlayan AB, Kılıç E, Günal MY, Uslu U, et al. Sodium Pentaborate Pentahydrate and Pluronic Containing Hydrogel Increases Cutaneous Wound Healing in vitro and in vivo. Biological Trace Element Research 2014;162(1-3):72-79. 